\title{
Desain Formulir Asesmen Nyeri dalam Berkas Rekam Medis di Rumah Sakit Daerah Balung Jember Tahun 2016
}

\author{
Faiqatul Hikmah ${ }^{1}$, Rossalina Adi Wijayanti', Moch Jach Catur Laksono ${ }^{1}$ \\ Jurusan Kesehatan, Politeknik Negeri Jember, Indonesia ${ }^{I}$ \\ e-mail :faiqatul@polije.ac.id
}

\begin{abstract}
Increasing the number of patients can be a consideration for recording a good and complete medical record so as to produce accurate information to support patient services. In Balung Jember Regional Hospital, the problem found was not doing pain assessment in detail for patients who complained of pain when they came in outpatient, emergency department, and inpatient care. The absence of a special form that records pain assessment in his medical record file. The purpose of this study is to design and design a medical assessment form for pain assessment sheets. The type of research used is descriptive qualitative method of observation, interviews, and focused discussion (brainstorming). This research resulted in identification of the physical aspects of the paper used is A4 paper with a weight of $70 \mathrm{gr}$ and white. The anatomical aspect is the location of the hospital's identity on the left with the hospital logo, the header or form title is on the left also in bold font. A command is printed on each entry. For the body to adjust the paper size. The content aspect is the completeness of the items, the ordering of items, grouping of items, abbreviations, symbols and ways of filling have been adapted to other forms and the needs of the user. The results of the design are then explained in a brainstorming focused discussion to obtain the final results agreed upon. This research is expected to be able to help in the service especially that is helping in the management of patients who complain of pain so that the treatment is more targeted.
\end{abstract}

Keywords: assessment, form design, pain

\section{Pendahuluan}

Permenkes, RI No. 269

(2008), rekam medis adalah berkas yang berisikan catatan dan dokumen tentang identitas pasien, pemeriksaan, pengobatan, tindakan dan pelayanan lain yang telah diberikan kepada pasien. Setiap dokter atau dokter gigi dalam menjalankan praktik kedokteran wajib membuat rekam medis dan harus dibuat segera dan dilengkapi setelah pasien menerima pelayanan. Catatan medis tersebut sangat penting untuk pelayanan pasien karena dengan data yang lengkap dapat memberikan informasi yang dapat dijadikan bukti perjalanan penyakit pasien dan pengobatan yang telah diberikan, alat komunikasi diantara para tenaga kesehatan yang memberikan perawatan kepada 
pasien, sumber informasi untuk riset dan pendidikan, serta sebagai sumber dalam pengumpulan data statistik kesehatan yang ditulis didalam sebuah lembar formulir.

Rekam medis terdiri dari dokumen rekam medis rawat jalan dan dokumen rekam medis rawat inap. Isi dari dokumen rekam medis rawat inap meliputi formulir ringkasan masuk keluar, surat pernyataan untuk dirawat, formulir persetujuan umum, formulir edukasi pasien dan keluarga yang terintegrasi, lembar sebab kematian, Resume asuhan keperawatan, catatan dokter, lembar perawat/bidan, resume medis, lembar pengkajian keperawatan, dll.

Menurut Arianto (2015), formulir rekam medis merupakan alat untuk pengumpulan data pasien dan merupakan bukti tertulis tentang proses pelayanan yang telah diberikan oleh dokter dan tenaga kesehatan lainnya kepada pasien, hal ini merupakan cermin kerja sama lebih dari satu orang tenaga kesehatan untuk menyembuhkan pasien. Informasi dalam rekam medis yang berkesinambungan dapat memudahkan petugas dalam memberikan layanan kesehatan kepada pasien serta dapat dijadikan dasar pertimbangan dalam perawatan lanjutan kepada pasien.

Berdasarkan Pedoman Penyelenggaraan dan Prosedur
Rekam Medis, Depkes RI (2006) menyatakan bahwa salah satunya formulir yang harus ada pada dokumen rekam medis adalah catatan keperawatan, dimana dalam catatan keperawatan terdapat asesmen pada pasien. Salah satu formulir yang ada di dalam asesmen pasien adalah formulir asesmen nyeri. Formulir asesmen nyeri berisi tata laksana nyeri yang dialami pasien.

Berdasarkan studi pendahuluan yang dilakukan pada bulan Maret 2016 di Rumah Sakit Daerah Balung Jember, peneliti mendapatkan hasil melalu observasi yaitu tidak di lakukannya asesmen nyeri secara merinci terhadap pasien yang mengeluhkan nyeri pada saat datang di rawat jalan, gawat darurat, dan rawat inap. Sehingga peniliti melakukan peninjauan dan tidak ditemukannya formulir untuk asesmen nyeri dalam berkas rekam medisnya. Menurut Herawati dan Sudayanto (2010), penanganan nyeri yang tidak dilakukan dapat menyebabkan berbagai komplikasi serta memperpanjang lama perawatan di rumah sakit, yang pada akhirnya meningkatkan biaya perawatan. Asesmen nyeri tidak di lakukan secara benar dan tidak ada lembaran khusus sebagai tempat pedokumentasian tindakan asesmen.

Berdasarkan uraian permasalahan diatas, maka peneliti tertarik untuk mengambil 
judul “ Desain Formulir Asesment Nyeri Dalam Berkas Rekam Medis Di Rumah Sakit Daerah Balung Jember Tahun 2016". Diharapkan dengan adanya desain formulir asesmen nyeri tersebut dapat menunjang pencatatan, pengumpulan, pengelolaan, penyajian, pembuatan laporan sehingga meningkatkan mutu rekam medis dan mutu pelayanan Rumah Sakit. Tujuan Penelitian ini adalah mendesain formulir rekam medis lembar asesmen nyeri di Rumah Sakit Daerah Balung Jember.

\section{Metode}

Jenis penelitian ini adalah penelitian kualitatif guna memperoleh kebutuhan perancangan formulir rekam medis lembar asesmen nyeri di Rumah sakit Daerah Balung Jember.

\subsection{Metode Pengumpulan Data}

Kebutuhan perancangan form asesmen nyeri dikumpulkan dengan cara wawancara dan observasi. Narasumber dalam penelitian ini adalah perawat, dokter dan kepala perekam medis.

Setelah perancangan form asesmen selesai dilakukan selanjutnya dilakukan brainstorming untuk mengetahui apakah desain form sudah berisikan informasi yang dibutuhkan pengguna.
Brainstorming dilakukan untuk mendapatkan saran dari pengguna demi kesempurnaan desain form yang telah dibuat.

\subsection{Metode Analisis Data}

Tahapan analisis data dalam penelitian ini antara lain reduction, data display, verification (Sugiyono, 2014).

Analisis data dilakukan untuk memperoleh informasi tentang kebutuhan perancangan form asesmen berupa aspek fisik formulir, aspek anatomi formulir, dan aspek isi formulir (Sulistyo dan Basuki, 2003). Hasil analisis kebutuhan perancangan tersebut selanjutnya digunakan sebagai dasar perancangan form asesmen.

\section{Hasil dan Pembahasan}

\subsection{Identifikasi Kebutuhan} Aspek Fisik Formulir Asesmen Nyeri

Berdasarkan
pengumpulan data yang di
lakukan dengan identifikasi
formulir contoh, observasi formulir lain yang digunakan dan hasil wawancara kepada 5 perawat yang terbagi di instalasi rawat jalan, rawat inap, dan gawat darurat terkait aspek fisik formulir asesmen nyeri dalam berkas rekam medis, dapat disimpulkan bahwa petugas menginginkan formulir asesmen nyeri terbuat dari kertas A4 mengikuti formulir lainnya yang sudah standar yang digunakan dalam berkas rekam medis 
dengan warna yang sama yaitu putih dengan berat $70 \mathrm{~g} 2 / \mathrm{m}$. Hal ini sesuai dengan pernyataan 2 orang perawat di instalasi rawat inap yaitu :

"nanti tujuannya ini kan ditaruh dalam berkas rekam medis ya dek. Jadi pake kertas A4 saja dek, terus beratnya pake yang kaya form lainnya $70 \mathrm{~g} / \mathrm{m}^{2}$ itu. Karena jika menggunakan kertas yang lain seperti form yang lama nanti ukurannya bisa tidak sama dek. Untuk warna sebaiknya warna putih saja"

\section{Menurut Huffman} (1999), terdapat lima aspek dari kertas yang perlu dipertimbangkan yaitu berat kertas sebanyak satu rim pada ukuran tertentu (weight), mutu kertas (grade), serat-serat pembuat kertas (grain), lapisan kertas (finish), dan warna kertas (color).

Sifat-sifat

ini berhubungan dengan permanency, durability, mutu penulisan kertas, keterbacaan, dan pembuatan microfilm. Dalam hal ini, permanency adalah jangka waktu kertas dapat disimpan. Durability adalah hubungan dengan kesanggupan seseorang untuk mengelola kertas berkali-kali. Mutu kualitas kertas mempengaruhi kemampuan seseorang untuk menulis dengan cepat, rata, dan kemampuan kertas untuk menerima tinta dari alat pencetakan.

Peneliti merumuskan aspek fisik berdasarkan hasil pengumpulan data yang dilakukan dengan cara observasi dan wawancara dengan mengidentifikasi aspek fisik formulir lain yang digunakan yaitu berbeda dengan pembuatan formulir - formulir lain yang menggunakan kertas F4 buram dengan ketebalan yang kurang dan mudah sobek.

Untuk pembuatan formulir asesmen nyeri dapat disimpulkan bahwa dari segi aspek fisik, pertugas menginginkan yaitu Bahan kertas HVS 70 gram, bentuk kertas persegi panjang dengan orientasi portrait, ukuran kertas A4 dengan panjang 29,7 cm dan lebar 21,5 $\mathrm{cm}$, warna kertas : putih dengan tinta hitam, kemasan folder berkas rekam medis.

\subsection{Identifikasi Kebutuhan Aspek Anatomi Formulir Asesmen Nyeri}

Berdasarkan hasil pengumpulan data yang di lakukan dengan identifikasi formulir contoh, observasi formulir lain yang digunakan dan hasil wawancara kepada 5 perawat yang terbagi di instalasi rawat jalan, rawat inap, dan gawat darurat terkait aspek anatomi formulir asesmen nyeri dalam berkas rekam medis, dapat disimpulkan bahwa petugas yang 
bertanggung jawab atas ruang penyimpanan berkas rekam medis serta pengadaan berkas atau formulir adalah kepala rekam medis. Sedangkan petugas yang mengisi formulir asesmen nyeri adalah perawat. Petugas menginginkan heading menyesuaikan seperti berkas rekam medis lain yang digunakan, isi dan tata letak item - item pada formulir asesmen nyeri jelas, sesuai dengan ukuran formulir lain yang digunakan dan mudah di pahami serta sewajarnya. Hal ini sesuai dengan pernyataan 2 orang perawat di instalasi rawat inap yaitu :

"Headingnya di tengah atas saja dek dengan huruf yang lebih besar dan tebal biar jelas. Untuk isinya menyesuaikan saja dengan aturan yang ada besarnya juga menyesuaikan dengan ukuran kertas. Kalau tata letaknya sama dengan form lain, menyesuaikan saja dan sewajarnya yang penting rapi dan jelas"

Aspek anatomi dalam merancang suatu formulir terdapat beberapa komponen yang meliputi kepala formulir (heading), pendahuluan (introduction), perintah (instruction), isi (body) dan penutup (close).

Kepala formulir (heading) yang digunakan mencakup identitas rumah sakit serta logo rumah sakit (menyesuaikan), tetapi ada penambahan judul formulir yaitu "Lembar Asesmen Nyeri". Pendahuluan

(introduction) dengan judul formulir yaitu "Lembar Asesmen Nyeri" karena judul formulir sudah mewakili dari tujuan formulir.

Perintah (instruction) pengisian formulir asesmen nyeri menggunakan tanda checklist $(\sqrt{ })$ untuk pilihan yang dipilih dan tanda $(\mathrm{O})$ untuk mengukurskala nyeri.

Isi (body) meliputi margin (margins) disesuaikan dengan kolom pada isi formulir, spasi (spacing) disesuaikan dengan kebutuhan item pada formulir, garis (rules) menggunakan garis langsung vertikal dan horizontal untuk membatasi tiap-tiap item di dalam formulir, jenis huruf (type style) diseragamkan menggunakan jenis huruf times new roman dengan ukuran $12 \mathrm{pt}$ kecuali untuk judul dibesarkan.

Penutup (close) tetap dengan format item tempat, tanggal, tanda tangan dan nama terang petugas yang mengisi.

\subsection{Identifikasi Kebutuhan Aspek Isi Formulir Asesmen Nyeri}

$\begin{array}{lr}\text { Berdasarkan } & \text { hasil } \\ \text { pengumpulan data } & \text { yang di } \\ \text { lakukan dengan identifikasi } \\ \text { formulir contoh, observasi }\end{array}$




\section{ISSN : 2354-5852 \\ e-ISSN : 2579-5783}

formulir lain yang digunakan dan hasil wawancara kepada 5 perawat yang terbagi di instalasi rawat jalan, rawat inap, dan gawat darurat terkait aspek isi formulir asesmen nyeri dalam berkas rekam medis, dapat disimpulkan bahwa petugas menginginkan formulir asesmen nyeri sebagai berikut :

"Untuk asesmen nyeri sebaiknya isinya lengkap yang pertama memuat data pasien, riwayat penyakit, riwayat pengobatan dll. Jadi tidak semata - mata isinya hanya mengukur seberapa rasa nyerinya. Kan ini untuk bisa menentukan selanjutnya"

penanganan

Aspek isi dalam merancang suatu formulir terdapat beberapa komponen yang meliputi kelengkapan item, pengelompokan, urutan, istilah, singkatan dan simbol.

Aspek kelengkapan item, butir item yang tercantum sama seperti yang sudah dtentukan dan di sepakati sebelumnya yaitu identitas rumah sakit, identitas formulir, identitas pasien, isi asesmen dan penutup.

Pengelompokan item disesuaikan dengan kelompok data yang sudah ditentukan sebelumnya. Dimulai dari kelompok identitas rumah sakit (nama rumah sakit), identitas formulir (nama formulir, identifikasi formulir), isi asesmen (skala nyeri, letak, durasi, karakter, dll) dan penutup (tempat, tanggal, tanda tangan dan nama terang petugas).

Urutan item disesuaikan dengan kelompok data yang sudah ditentukan sebelumnya. Dimulai dari kelompok identitas rumah sakit, identitas formulir, isi asesmen dan penutup. Istilah yang digunakan di dalam formulir asesmen nyeri menyesuaikan seperti yang sudah digunakan pada formulir formulir lain dan tidak sulit untuk dipahami oleh pengguna.

Singkatan yang digunakan di dalam formulir asesmen nyeri menyesuaikan seperti yang sudah digunakan pada formulir - formulir lain yang digunakan yang mudah dipahami.

Simbol yang digunakan di dalam formulir asesmen nyeri menyesuaikan seperti yang sudah digunakan pada formulirformulir lain dan tidak sulit untuk dipahami oleh pengguna.

Cara Pengisian formulir asesmen nyeri di Rumah Sakit Daerah Balung Jember dilakukan dengan cara manual yaitu ditulis tangan oleh perawat maupun dokter yang memberikan asesmen nyeri kepada pasien di instalasi rawat jalan, rawat inap, dan gawat darurat.

Hasil desain formulir asesmen nyeri dalam berkas rekam medis di rsd balung 
jember dapat dilihat pada gambar 1 dan gambar 2.

Berdasarkan hasil observasi yaitu tidak adanya formulir khusus yang digunakan untuk melakukan asesmen nyeri maka di desainlah sebuah formulir yaitu formulir asesmen nyeri. Hasil desain yang telah dibuat berdasarkan identifikasi formulir contoh dan hasil wawancara kebutuhan pengguna kemudian dipaparkan dalam forum diskusi bersama guna mendapatkan hasil akhir desain yang sesuai dengan teori yang ada.

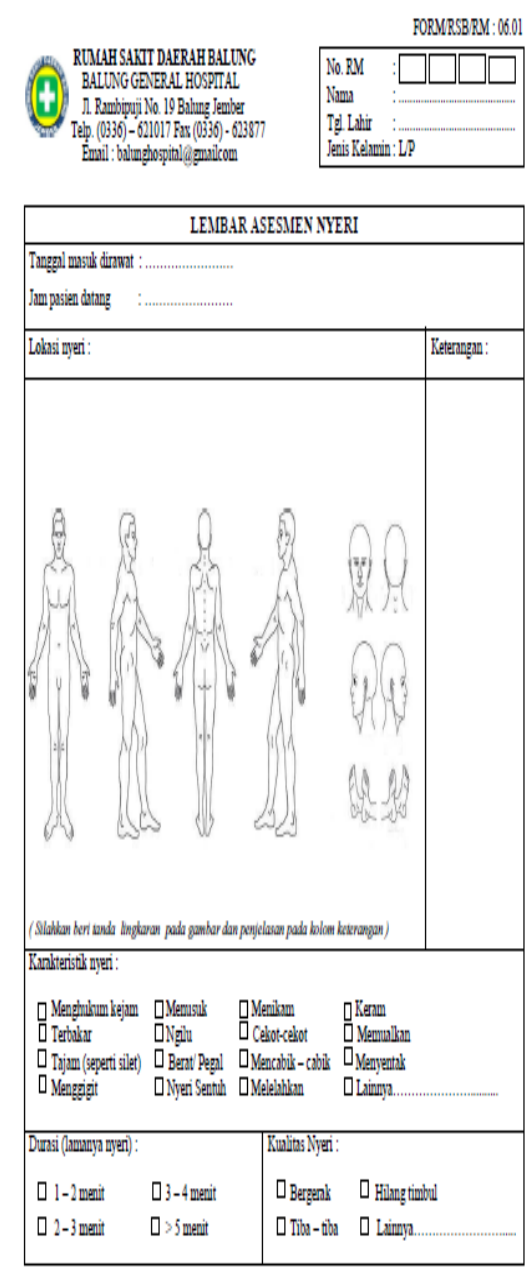

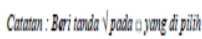

Gambar 1. Desain form asesmen nyeri halaman 1 
FORMRSBRU: 0601

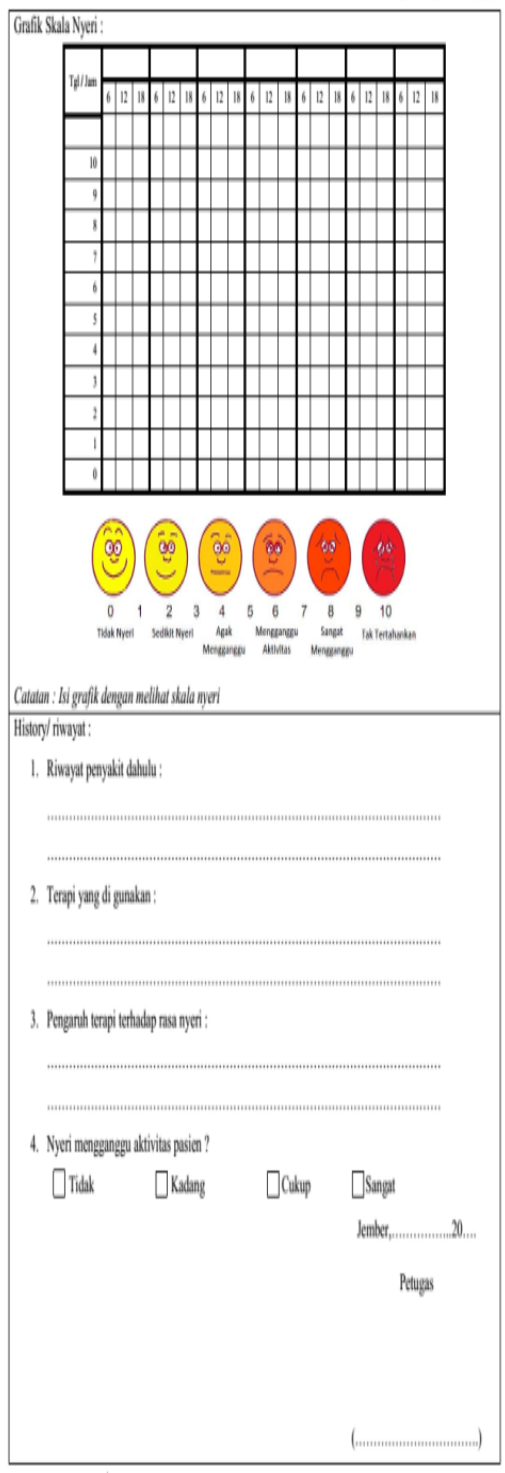

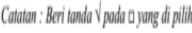

Gambar 2. Desain form asesmen nyeri halaman 2

Berdasarkan hasil diskusi bersama (brainstorming) dengan jumlah informan yang hadir sebanyak 6 orang yang terdiri dari 2 perawat ruang rawat inap dahlia, 2 perawat instalasi gawat darurat, 1 perawat instalasi rawat jalan dan 1 kepala perekam medis mengenai aspek fisik formulir asesmen nyeri dalam berkas rekam medis didapati hasil sebagai berikut :

"Dari segi aspek fisik. Kertas yang digunakan adalah A4 dengan berat $70 \mathrm{gr}$ jadi tidak terlalu tebal jika disimpan dalam berkas rekam medis nantinya. Warnanya juga sudah sesuai yaitu putih."

Hal ini sesuai dengan teori dari Riyadhy Noor dalam Whardani (2015) bahwa bahan yang digunakan untuk formulir yang disimpan/diabadikan sebaiknya yang tidak mudah robek minimal HVS 70 gram, warnanya cerah dan biasanya bentuk formulir adalah persegi panjang.

Terkait aspek fisik desain formulir asesmen nyeri diatas yaitu menggunakan kertas A4 dengan berat 70 gram dan berwarna putih. Hasil yang di dapat berdasarkan hasil wawancara kebutuhan pengguna, teori aspek fisik formulir dan juga terakhir dari diskusi bersam brainstorming.

Dari segi aspek anatomi berdasarkan hasil wawancara (dapat dilihat pada lembar wawancara) dan di lanjutkan dengan diskusi bersama 
brainstorming di dapatkan hasil yaitu :

"Heading nya sudah cukup jelas memuat identitas rumah sakit. Pendahuluan juga memuat judul dari lembar tersebut yang sudah menjelaskan tujuan dari formulir. Untuk bagian body formulir juga di rasa sudah pas dengan kertas yang di gunakan."

Judul harus berada di atas sehingga informasi kontrol yang berhubungan bisa terlihat di bagian dasar (Huffman, 1999). Desain formulir asesmen nyeri di atas untuk badan formulir diberi garis-garis batas pengisian agar lebih rapi dan mudah membacanya serta jenis huruf diseragamkan semua menggunakan jenis times new roman ukuran $12 \mathrm{pt}$ kecuali untuk judul ukuran huruf lebih besar.

Sebuah garis membagi formulir atas bagian-bagian logis, mengarahkan penulis untuk memasukkan data pada tempat yang semestinya (Huffman dalam Budi, 2013). Sedangkan untuk bagian penutup (close) yaitu tempat, tanggal, tanda tangan dan nama terang petugas.

Dari segi aspek isi berdasarkan hasil wawancara (dapat dilihat pada lembar wawancara) dan di lanjutkan dengan diskusi bersama brainstorming di dapatkan hasil :
"Untuk aspek isi, semuanya di rasa sudah sesuai dengan teori yang ada dan mewakili pencatatan yang memang di butuhkan untuk asesmen nyeri..."

Item assesment yang standart menurut model desain formulir pengkajian keperawatan RSUP dr. Sardjito menggunakan kejelasan kata, istilah medis, pengelompokkan, pengurutan, pembagian item yang sama rata, pengisian yang baik, dan beberapa item assesment tersebut adalah identitas rumah sakit, identitas pengkajian, identitas pasien, riwayat pasien, pemeriksaan umum, pemeriksaan fisik, pemeriksaan penunjang, pola nutrisi pasien, daftar masalah, daftar alergi, sebab luar perlukaan, program terapi dokter, nama terang, tanda tangan, tanggal dan jam pengkajian.

Aspek isi dalam desain formulir asesmen nyeri diatas yaitu memuat identitas pasien, isi asesmen dan penutup. Untuk pengelompokan dan pengurutan juga telah di sesuaikan dengan data yang telah di tentukan sebelumnya. Penggunaan singkatan, istilah, dan simbol juga disesuaikan dengan formulir lain yang di gunakan oleh pengguna.

\section{Simpulan dan Saran}

\subsection{Simpulan}

Berdasarkan hasil dan pembahasan penelitian mengenai 
"Desain Formulir Asesmen Nyeri Dalam Berkas Rekam Medis di Rumah Sakit Daerah Balung Jember Tahun 2016" yang telah dilaksanakan di Rumah Sakit Daerah Balung Jember, maka dapat diperoleh kesimpulan sebagai berikut :

1. Aspek fisik formulir asesmen nyeri meliputi jenis kertas yaitu menggunakan kertas Art Paper 4 dengan berat kertas 70 gr, ukuran kertas yaitu panjang $29,7 \mathrm{~cm}$ dan lebarnya $21,5 \mathrm{~cm}$ dan warna kertas yaitu putih. Formulir asesmen nyeri memiliki warna dan jenis kertas yang sama dengan formulir lain yang di gunakan.

2. Aspek anatomi formulir asesmen nyeri meliputi kepala formulir (heading), pendahuluan

(introduction), perintah (intruction), dan badan formulir (body) menyesuaikan dengan formulir lain yang ada namun tetap sesuai dengan tujuan formulir dibuat.

3. Aspek isi formulir asesmen nyeri meliputi identitas pasien (nomor rekam medis, umur, jenis kelamin tanggal di rawat, nama dan alamat), item assesment (skala nyeri, letak, durasi, karakteristik nyeri, kondisi nyeri dan riwayat nyeri).

4. Hasil rancangan di dapatkan melalu identifikasi formulir contoh, observasi formulir lain yang digunakan dan wawancara kebutuhan pengguna dan diteruskan dengan diskusi terfokus brainstorming untuk mendapatkan desain akhir.

\subsection{Saran}

Dalam penelitian ini, peneliti mengusulkan beberapa saran yang nantinya dapat dijadikan sebagai bahan saran dan masukan yang bermanfaat untuk penggunaan formulir asesmen nyeri, yaitu :

1. Perlunya evaluasi formulir secara berkala dengan memperhatikan kebutuhan pengguna akan aspek asesmen dari waktu ke waktu.

2. Untuk peneliti selanjutnya di harap dapat mengembangkan dalam model rekam medis elektronik.

\section{Daftar Pustaka}

Arianto, Nyol. (2014). Perancangan Ulang Formulir Rekam Medis Ringkasan Masuk Dan Keluar Di Rumah Sakit Umum Mawar Banjarbaru Tahun 2014. Skripsi. Program Studi Perekam 
Dan Informasi Kesehatan. Sekolah Tinggi Ilmu Kesehatan Husada Borneo Banjarbaru

Budi, Savitri Citra. (2011). Manajemen Unit Kerja Rekam Medis. Yogyakarta: Quantum Sinergi Media.

Depkes RI. (2006). Pedoman Penyelenggaraan dan Prosedur Rekam Medis Rumah Sakit di Indonesia Revisi II. Jakarta.

Herawati, E. dan Sudiyanto, A. (2010). Keefektifan Logoterapi terhadap Penurunan Intensitas Nyeri dan Skor Depresi Pasien Nyeri Kronik di Poliklinik Rehabilitasi Medik RSDM Surakarta.

Hatta, Gemala. (2008). Pedoman Manajemen Kesehatan di Sarana Pelayanan Kesehatan. Jakarta: Penerbit Universitas Indonesia.

Huffman, Edna K. (1999). Health Information Management 10th Ed. Berwyn, Illionis: Physicians' Record Company.

Sugiyono. (2014). Memahami Penelitian Kualitatif. Bandung: Penerbit Alfabet.
Sulistyo dan Basuki. (2003).

Manajemen

Dinamis. Arsip Gramedia Pustaka Utama. 